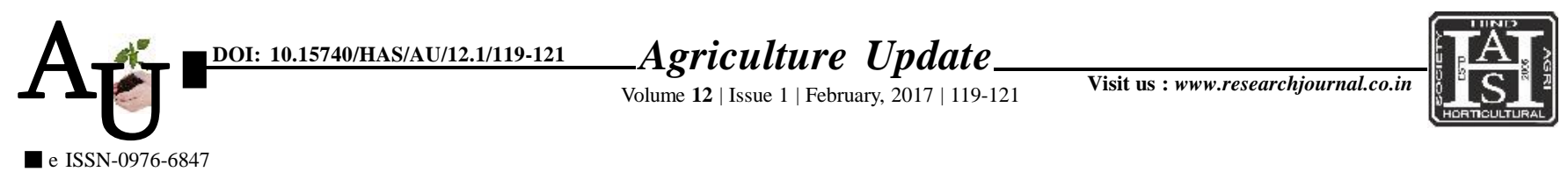

\title{
Research Article: Assessment of the knowledge level of potato growers in Madhya Pradesh
}

\section{RAJKUMARI RAGHUWANSHI, M.M. PATEL, NEERJA PATEL AND SANDEEP CHOUHAN}

Article Chronicle: Received :

04.11.2016;

Revised :

07.01.2017;

Accepted :

14.01.2017

Key WoRds:

Assessment,

Knowledge level,

Potato growers

Author for correspondence :

\section{RAJKUMARI}

RAGHUWANSHI

Rajmata Vijayaraje

Scindia Krishi

Vishwavidyalaya,

GWALIOR (M.P.) INDIA

See end of the article for

authors' affiliations
SUMMARY : The study was conducted to assess the knowledge level of potato growers in Gwalior district of Madhya Pradesh. The productivity level of potato is observed to be low in Madhya Pradesh due to various reasons among these are climate and adoptability of technologies. Potato production has played a vital role in increasing vegetable production of the country with 25.6 per cent share in total vegetable production during 2002-03. The contribution of the country in world potato pool has increased from 6.4 per cent to 7.8 per cent during last decade. Potato utilization has become more diverse with processed products commanding a large share of the potato market. Majority of the potato growers had complete knowledge about improve varieties. The data also indicated that majority of the potato growers were aware about recommended spacing (59.17\%), disease management (56.67\%) and selection of field $(52.5 \%)$.

How to cite this article : Raghuwanshi, Rajkumari, Patel, M.M., Patel, Neerja and Chouhan, Sandeep (2017). Assessment of the knowledge level of potato growers in Madhya Pradesh. Agric. Update, 12(1): 119-121; DOI : 10.15740/HAS/AU/12.1/119-121. 